\title{
Teologia das religiões para além do aspecto doutrinário
}

\section{Theology of religions beyond the doctrinal aspect}

\section{Teología de las religiones más allá del aspecto doctrinal}

\author{
Alonso de S. Gonçalves*
}

\begin{abstract}
RESUMO
A proposta do presente artigo é discutir alguns critérios na abordagem das religiões em curso pela teologia. Essa relação entre teologia e religiões, se dá, principalmente, por conta do pluralismo religioso e do necessário diálogo inter-religioso. É sabido que o debate em torno do tema conta com diferentes enfoques e perspectivas. Esse desafio se constitui motivador, uma vez que a temática - a relação entre teologia e religiões -, está envolvida na terminologia conhecida como teologia das religiões. A nossa hipótese é de que alguns critérios para esse esforço (relação entre teologia e religiões), ainda são poucos explorados, ou evitados, como o status epistemológico de uma teologia que quer pensar o fenômeno religioso antes do enquadramento doutrinário de uma determinada experiência religiosa.

Palavras-chave: Teologia das religiões; pluralismo religioso; fenômeno religioso.
\end{abstract}

\begin{abstract}
The purpose of this proposal is to discuss some criteria in the approach of the religions under way in theology. This relationship between theology and religions is mainly due to religious pluralism and, if necessary, interreligious dialogue. It is well known that the debate around the theme has different approaches and perspectives. This challenge is motivating, since the theme - the relationship between theology and religions - is involved in the terminology known as theology of religions. Our hypothesis is that some criteria for this effort (relationship between theology and religions) are still few explored or avoided, such as the epistemological status of a theology that wants to think the religious phenomenon before the doctrinal framework of a certain religious experience.
\end{abstract}

Keywords: Theology of religions; religious pluralism; religious phenomenon.

\section{RESUMEN}

La propuesta aquí prevista, es discutir algunos criterios en el enfoque de las religiones actuales por la teología. Esta relación entre la teología y las religiones, principalmente por el pluralismo religioso y, si es necesario, el diálogo interreligioso. Se sabe que el debate alrededor del tema tiene diversos enfoques y perspectivas. Este desafío es motivadora, ya que el tema - la relación entre la teología y las religiones-, participa en la terminología conocida como teología de las religiones. Nuestra hipótesis es que algunos criterios a este esfuerzo (relación entre la teología y las religiones), sin embargo, pocos son explotados o evita, como el estatuto epistemológico de una teología que quiere pensar el fenómeno religioso antes del marco doctrinal de un particular experiencia religiosa.

Palabras clave: Teología de las religiones; pluralismo religioso; fenómeno religioso.

\footnotetext{
Doutorando e Mestre em Ciências da Religião (2014); Licenciatura em Filosofia (2006); Bacharel em Teologia (2004). Realiza estudos, com o apoio da FAPESP (Fundação de Amparo à Pesquisa do Estado de São Paulo - Processo n. ${ }^{\circ}$ 2017/09589-8) na Universidade Metodista de São Paulo, pesquisando Teologia das Religiões e Diálogo Inter-religioso a partir da Teologia Protestante. Contato: alonso3134@hotmail.com.
} 


\section{Introdução}

Esse texto surge de uma inquietação quanto à relação teologia das religiões e diálogo inter-religioso. A discussão em torno do tema - teologia e sua relação com as religiões - tem sido profícua e necessária em tempos de cultura globalizada e, ao mesmo tempo, fragmentária. A proposta que aqui se apresenta é discutir alguns critérios na abordagem das religiões em curso pela teologia. Essa relação entre teologia e religiões, se dá, principalmente, por conta do pluralismo religioso e do necessário diálogo inter-religioso. É sabido que o debate em torno do tema conta com diferentes enfoques e perspectivas. Esse desafio se constitui motivador, uma vez que a temática - a relação entre teologia e religiões -, está envolvida na terminologia conhecida como teologia das religiões ou teologia do pluralismo religioso. Reflexão que vem somando articulações de teólogos católicos e protestantes, principalmente dos primeiros e, escassamente ainda, dos segundos.

A nossa hipótese é que alguns critérios para esse esforço (relação entre teologia e religiões), ainda são poucos explorados, ou evitados, como o status epistemológico de uma teologia que quer pensar o fenômeno religioso antes do enquadramento doutrinário de uma determinada experiência religiosa. Percebemos que isso ocorre por conta da discussão que se dá em torno do conceito teologia das religiões, ainda muito marcado por questões dogmáticas. Sabemos que essa terminologia procura ser uma chave de leitura, a partir da teologia cristã, que tem como fim proporcionar uma reflexão em tempos de pluralismo religioso (TEIXEIRA, 1995, p.12). Nesse intento, a teologia das religiões quer ser promotora de uma reflexão em que a teologia cristã, com seu arcabouço teológico, tenha condições sistêmicas para o diálogo com outras expressões religiosas, mas tendo como pré-condição uma revisão de seus pressupostos teológicos, para que seja possível uma abertura para o outro que, assim como o cristianismo enquanto experiência religiosa, possui valores teológicos e pontos comuns que possibilitam o diálogo. Por essa razão, que Claude Geffré insiste na ideia de que a "teologia das religiões se tornou um dos capítulos mais vivos da teologia contemporânea" (2013, p.43), ou seja, a primeira tarefa da teologia nesse tempo é produzir uma teologia das religiões que tenha como principal foco o pluralismo religioso. Nessa direção, procurando alinhar teologia "cristã" das religiões e pluralismo religioso, está José María Vigil, que sentencia: "A teologia das religiões ou do pluralismo religioso é teologia, ou seja, reflexão à luz da fé sobre pluralismo religioso, quer dizer, sobre a pluralidade das religiões, sobre o fato de que a religião não seja uma, senão muitas" (2006, p.13). O conceito (teologia das religiões), ao que tudo indica, está condicionado à reflexão que a teologia cristã faz, ou procura fazer, 
a partir de sua própria concepção teológica, sobre as demais religiões. Nesse sentido, é uma teologia cristã das religiões. Um esforço legítimo e necessário. Hoje, o tema da teologia das religiões tem sido amplamente disseminado por diversos autores cristãos, que procuram colocar em pauta a necessidade de uma reflexão séria que contemple um status de alteridade em relação às demais religiões, e esse empreendimento tem proporcionado profundas e interessantes contribuições para o debate. Assim, como tema prioritário na teologia hodierna, e expressivo, principalmente entre teólogos de tradição católica, a teologia cristã das religiões, dentro de sua dimensão dialógica, se divide quanto aos seus intérpretes, tendo, pelo menos, três modelos-direções: (1) a exclusivista, que postula um fechamento em torno da figura de Jesus e da Igreja como condição salvífica, vertente presente tanto no catolicismo (integrismo) quanto no protestantismo histórico (fundamentalismo). Mas aqui há uma crítica de que esse modelo-direção não se constitui em uma opção para a teologia cristã das religiões, por ser negativa ao diálogo, uma vez que a própria palavra já deixa evidente que não há possibilidade de diálogo, quando há uma postura exclusiva; (2) a inclusivista, em que se aceita valores positivos das demais tradições religiosas, mas ainda não confere status salvífico; (3) a pluralista, popularizada por teólogos como John Hick (2005), por exemplo, em que há o reconhecimento de que em outras tradições religiosas há legitimidade e autonomia salvífica. Pelo que percebemos, o debate se dá em torno da questão salvífica, havendo debates entre teólogos católicos que se dividem em distintas perspectivas cristológicas quanto ao alcance da salvação em outras tradições religiosas. Discussão necessária, mas, no nosso entender, não premente, uma vez que há algo anterior à interpretação doutrinária ou ritualista de uma determinada tradição religiosa, que se constitui como fenômeno que não se dá, precisamente, como um dado sistematizado e definido. É nesse sentido que pretendemos caminhar com esse texto, ou seja, quer ser uma modesta contribuição no sentido de propor alguns pressupostos epistemológicos que ampliem modelos-direções teológicas a partir de posturas enrijecidas e doutrinárias. Com isso, entendemos ser possível empreender um projeto de diálogo entre-fés, partindo de algumas constatações na contemporaneidade, que envolva uma teologia que priorize a linguagem, sendo, portanto, uma teologia hermenêutica, como um modelo na relação entre teologia e religiões. Quanto ao diálogo inter-religioso, propriamente, não será abordado nesse texto, sendo objeto de reflexão em outra oportunidade. Aqui, a prioridade será os conceitos e a possibilidade, ou não, de refletir em uma teologia das religiões que não tenha, primeira e necessariamente no aspecto doutrinário o seu principal elemento. 


\section{A contemporaneidade e a teologia}

A busca por nomear este tempo tem sido incansável e disputada (LATOUR, 2013, p.15). Estamos nos referindo ao debate que envolve modernos e pós-modernos na tentativa de ler a contemporaneidade. Essa discussão é tão intensa que há pelo menos um consenso entre os teóricos, qual seja, de que não há unanimidade epistemológica que dê conta de um contexto tão diversificado e plural como o nosso (GONÇALVES, 2010, p. 14). Com isso, há autores, das diversas áreas do saber, que se dedicam a entender este tempo, dando perspectivas e prospectivas para uma era marcada por alguns elementos mensuráveis e dinâmicos que configuram a cultura. As percepções que ajudarão a fazer um possível diagnóstico do presente dependem do teórico que se lê para compreender este tempo. Nesse sentido, preferimos o termo contemporâneo (ou contemporaneidade), por entender que ele pode dar conta de uma nomeação que, até o momento, continua aberta. Quando fazemos a opção por contemporâneo para nomear esse tempo, estamos nos aproximando de uma definição que Giorgio Agamben forneceu do que seja o contemporâneo: "Uma relação singular com o próprio tempo, que adere a ele e, ao mesmo tempo, toma distância dele" (2015, p.22). O contemporâneo se dá a partir do momento em que há uma dissociação do tempo, mesmo tendo uma relação com ele. Assim, para Agamben, "aqueles que coincidem muito plenamente com a época, que se ligam em todos os pontos perfeitamente com ela, não são contemporâneos porque, exatamente por isso, não conseguem vê-la” (2015, p.23). Para ver essa época, não é possível estar ligado plenamente com ela. Como ser contemporâneo em uma era de mudanças e idiossincrasias? O "contemporâneo é aquele que mantém fixo o olhar no seu tempo, para perceber não as suas luzes, mas a escuridão [...]. Contemporâneo é, exatamente, aquele que sabe ver essa obscuridade, que é capaz de escrever mergulhando a pena nas trevas do presente" (AGAMBEN, 2015, p.25). Há, portanto, alguns que são contemporâneos e conseguem enxergar pontos de luz na escuridão. Nesse sentido, há autores que fazem uma leitura do tempo em que os pontos de luz lhes são perceptíveis.

Quando pensamos em teologia e contemporaneidade, buscamos ver fachos de luz em uma era marcada pela obscuridade, principalmente quando a personagem mais progressista no momento é o Papa Francisco, por exemplo. Para a teologia ter condições de se fazer contemporânea, ela precisa "perceber a escuridão do seu tempo como algo que lhe diz respeito e não cessa de interpelá-lo" (AGAMBEN, 2015, p.26). É aqui que postulamos uma tentativa de conceber a teologia não como ciência, em que a busca por um status epistemológico é combativo com os demais saberes, a fim de 
sentar ao lado deles com prioridade. ${ }^{1}$ Isso, para a teologia, não é mais possível. Essa definição de teologia como "ciência da fé e, por consequência, estudo organizado, metódico e sistematizado sobre Deus, visto como seu objeto ôntico, apoiado na filosofia, em sua condição de ciência ontológica" (GONÇALVES, 2010, p.42) não se concebe, ainda mais quando a ciência(s) não é tida mais como soberana e determinante. Antes, foi revista em seus pressupostos, constatando-se seu status hermenêutico e casuístico (PRIGOGINE, 2011). A teologia na contemporaneidade, ao nosso ver, deveria procurar respirar outros ares. Nesse sentido, é preciso seguir com Rubem Alves: "Durante séculos os teólogos, seres cerebrais, haviam se dedicado a transformar a beleza em discurso racional. A beleza não lhes bastava. Queriam certezas, queriam verdades [...]. Quero uma teologia que esteja mais próxima da beleza que da verdade" (apud LAGO, 2009, p.68). De um modo diferente, mas também contemporâneo, Jürgen Moltmann dirá: “A teologia não é uma ciência objetiva sobre dados constatáveis e fatos que podem ser comprovados. Ela não pertence ao âmbito do saber que dispõe sobre os objetos, mas ao âmbito do saber que sustenta a existência, que nos dá coragem para a vida" (2004, p.31). Uma teologia que busca ser contemporânea necessita fazer fissuras nos discursos enrijecidos pelo doutrinário. Do contrário, não será possível encontrar beleza, nem mesmo ver fachos de luz na obscuridade da presente era.

Se o propósito é pensar uma teologia que seja possível a partir de um contexto marcado pelo pluralismo religioso, decorrente das transformações culturais e religiosas, essa teologia precisa se despir de alguns apetrechos que a colocaram como detentora incólume da verdade. Ainda caberia uma reflexão teológica das religiões pautada na "verdade" e, ainda mais, sendo a teologia cristã a portadora incontestável de tal verdade? Pensamos que não. Entendemos que os recursos da linguagem e da hermenêutica podem contribuir para se pensar em uma teologia das religiões que não foque, peremptoriamente, no aspecto doutrinário, uma vez que este, per si, se dá como construção discursiva sobre a Realidade. ${ }^{2}$

Procuramos tratar desse tema aqui: GONÇALVES, Alonso S. Uma linguagem pública para a teologia, Correlatio, n. 27, 2015, p. 43-51.

2 “A religião não é um mero subproduto de condições históricas específicas, mas uma articulação da linguagem simbólica e dos processos de consciência de alto nível [...]. O modo narrativo é o produto por excelência da linguagem e uma das formas de modelização do mundo mais importantes da cultura. E, se a linguagem tem como seu mais importante produto a narrativa, o mito é a narrativa por excelência” (NOGUEIRA, 2013, p. 448-449). 


\section{Teologia como linguagem e hermenêutica}

Obviamente, teologia é linguagem. Teologia é sempre um discurso de quem a formula (hermenêutica), portanto, não poderia haver uma teologia que contemple todas as experiências religiosas. Daí, a pretensão de encapsular a teologia como cristã de maneira peremptória apresenta dificuldades. A identificação da teologia como teologia cristã encerra problemas, principalmente quando admitido que teologia é algo anterior ao cristianismo. Os gregos já haviam pensado em teologia antes do cristianismo. Para Platão, por exemplo, teologia estava relacionada com "narrativas míticas sobre os deuses contadas pelos poetas, especialmente Homero e Hesíodo" (GROSS, 2008, p.324-325). Quem identifica teologia com metafísica é Aristóteles. Para este, “a teologia trataria não de símbolos, mitos e narrativas, mas da realidade do divino como ele realmente é. E tratar disso, sem poesia obviamente, seria condição para compreender bem a realidade do mundo" (GROSS, 2008, p.326). Dentre as duas perspectivas, a teologia como metafísica logrou êxito por um tempo, até que a chamada modernidade destronou essa aliança que promoveu todo o período da Idade Média. Mesmo depois das inúmeras questões levantadas pela modernidade e suas implicações para a política, a religião e a teologia, ainda é possível ver os resquícios dessa aliança, perceptíveis na construção teológica cristã. No caso da teologia católica, por exemplo, há uma constante vigilância para não se romper com o discurso teológico produzido pela Tradição, quando diante das demandas da contemporaneidade. Não por acaso, teólogos que procuram pensar em temas teológicos que, em algum momento, não coadunam com a perspectiva do Magistério, recebem notificações em suas obras, independentemente de onde estão geograficamente. Assim, é possível ver o devido cuidado de teólogos católicos quando definem a teologia e sua tarefa nesse tempo: "Toda teologia que se pretende séria e inserida na cultura a que pertence deve se firmar em escutar a fé pela Escritura e pela Tradição" (GONÇALVES, 2010, p.45). Por essa razão, a noção de verdade se dá como conceito inegociável na teologia católica (não somente na católica, como também protestante). A esse pressuposto (verdade), que a teologia se constitui como ciência, rogando, inclusive, a primazia como tal. Revestindo a teologia como discurso científico, ela reivindica a univocidade da verdade: "Há uma só verdade que, em parte, pode ser reconhecida pela razão e a observação, e outra foi revelada por Deus mediante a Bíblia" (ZILLES, 2011, p.65). Obviamente, essa declaração está fundada em um aparato metafísico, portanto, "a noção de verdade como correspondência entre uma proposição e a coisa a que está se refere é pressuposto comum 
na metafísica ocidental" (GROSS, 2008, p.328). Não sem razão, esta noção de verdade é compartilhada "por várias formas dogmáticas de teologia" (GROSS, 2008, p.328).

Teologia como linguagem e hermenêutica envolve a discussão da ideia de revelação. Concordamos que a revelação é um pressuposto da teologia, mas a concepção de revelação pode ser tratada de outra maneira que não prontamente como metafísica. Isso é o que propõe o filósofo italiano Giorgio Agamben, como veremos adiante. Há um acordo de que a teologia que se faz contemporânea se faz a partir da linguagem. Mesmo assim, a junção teologia-linguagem-hermenêutica é pensada com propriedades revelacionais:

Ainda que se possa conceber o desenvolvimento de uma teologia hermenêutica na era contemporânea, o que se requer na elaboração de uma teologia pós-moderna é uma hermenêutica teológica. Isso significa que a teologia, não abdicando da hermenêutica, desenvolver-se-á sempre no processo de compreensão e interpretação do evento da revelação - elemento central em seu caráter científico (GONÇALVES, 2010, p.63).

Ocorre que todo procedimento hermenêutico implica em certos critérios de interpretação. Daí que a questão reside na escolha de certos critérios interpretativos. Aqui, seguimos Hans-Georg Gadamer (1999), por entender que ele oferece certos critérios para uma interpretação que leve em consideração o estado do interpretante e aquilo que está sendo interpretado com certa autonomia na produção de sentido.

Para Gadamer, a historicidade do compreender é construída da seguinte maneira: compreende-se o mundo por meio da interpretação; sem esta, é impossível fazer uma leitura da realidade e da história. À história pertence a tradição, ou seja, somos seres que fomos influenciados por tradições do passado e essas tradições já são consequências interpretativas. Nesse caso, Gadamer entende que não atingimos a realidade através de um conhecimento de tipo imediato, como quer o empirismo, por exemplo. Toda constatação de alguma coisa pressupõe um sujeito, e todo sujeito pressupõe um contexto histórico. A interpretação só acontece porque há predisposições e preconceitos como elementos constitutivos do ato de interpretar. Diante disso, a hermenêtica se dá essencialmente na história que em seu movimento produz tradição que, por sua vez, influencia o interpretante em suas predisposições e preconceitos para uma compreensão do mundo. Sendo assim, a pré-compreensão é, per si, um pressuposto necessário para a compreensão que, comitantemente com a tradição, dará o sentido para o interpretante. Com estas concepções, Gadamer trata a historicidade da compreensão como elemento hermenêutico (OLIVEIRA, 2001, p.229). Isso se dá porque, para Gadamer, o ser humano pertence à 
história, e pertencer significa estar ligado a uma tradição histórica, a uma língua, a uma cultura, e, todos esses elementos determinam a pré-compreensão do interpretante (RIPANTI, 1998, p.376). O círculo hermenêutico se dá a partir do sujeito que experimenta o mundo sempre com algum sentido. A esse sentido, Gadamer chama de pré-compreensão, ou predisposições, sendo esses elementos sempre presentes por meio da experiência do sujeito. Sendo assim, a "hermenêutica é essencialmente uma reflexão sobre a influência da história, ou seja, uma reflexão que tem como tarefa tematizar a realidade" (OLIVEIRA, 2001, p. 230).

O círculo hermenêutico de Gadamer parte do seguinte pressuposto: o sujeito interpretante, que no decorrer de sua vida absorveu certo patrimônio cultural e esse patrimônio cultural, que foi sendo gestado no transcorrer da história, é que possibilita o elemento da pré-compreensão (1999, p.416).

Diante do exposto, tomando a concepção hermenêutica gadameriana, é possível perguntar: a revelação é algo que está fora da linguagem? Se for algo de fora, caberia a hermenêutica? Essas são algumas questões que pretendemos discutir a partir de agora para que, num terceiro momento, pensemos na teologia e sua relação com as religiões e os desdobramentos dessa relação, tais como o pluralismo religioso e o diálogo inter-religioso.

\section{Revelação como linguagem}

O tema da revelação é o principal pressuposto para a teologia. Mesmo admitindo que a revelação se faz a partir da linguagem e da cultura, a teologia concebe uma revelação que vem de fora, ou seja, há um pressuposto de que essa revelação é perfeita, porque está no próprio "Deus". O que ele (Deus) fez, foi usar meios para se revelar em "sua infinita sabedoria, se manifestar aos seres humanos" (SANTANA FILHO, 2008, p.877). O fundo dessa concepção, se procuramos na filosofia, está em Platão e Aristóteles, mas, também, de forma bem acentuada, em Kant. O impacto que a filosofia kantiana exerceu na reflexão teológica é indelével. ${ }^{3}$ Assim, o argumento ontológico "confere conteúdo ao conceito do ente necessário, isto é, existente por si mesmo, a partir da ideia, denominada por Kant 'ideal transcendental', do ser mais perfeito" (PANNENBERG, 2008, p.171). A ontologia será trabalhada na teologia como seu fundamento, e o teólogo Karl Rahner, por exemplo, terá no método transcendental a construção da sua teologia, dando um novo eixo para o que seria antropologia transcendental. Com o postulado de que a razão não se faz "capaz" de apreender "Deus", está dado o sentido

3 Um estudo que interpreta a concepção de religião e teologia em Kant: HERRERO, Francisco Javier. Religião e história em Kant. São Paulo: Loyola, 1991. 
ontológico, ou seja, é preciso afirmar "uma necessidade metafísica arraigada no ser próprio do homem” (ZILLES, 2002, p.52). O debate em torno da metafísica já foi maior, sendo consenso de que a metafísica, elemento imprescindível em algumas leituras teológicas, não dá conta quando algumas perguntas foram feitas no século 20. Filósofos como Habermas e Vattimo, por exemplo, tratam dessa mudança paradigmática na filosofia, falando em pós-metafísica. Autores que olham atentamente para as obras de Nietzsche concluem, com as devidas diferenças, que o mesmo já tinha superado a metafísica, por entender que esta exerce função castradora no ser humano quando o remete para uma essência que não cabe para o humano emancipatório que quer amar a vida e suas contingências (SOUSA, 2009, p.25). Assim, tem-se a impressão de que o evento da revelação ficou deslocado enquanto absurdo e dado inevitável. As tentativas de alocar a revelação a partir de metanarrativas ou preposições parecem não caber em um contexto que mudou a concepção de olhar o que vem.

Heidegger, por exemplo, dedicou todos os seus esforços a investigar o sentido do Ser. O alvo fundamental da sua construção filosófica é o questionamento do esquecimento do ser como problema filosófico. No seu empenho, Heidegger quer formular uma nova ontologia, totalmente dirigida ao problema do ser. Assim, ele concentra em sua filosofia o humano, uma vez que somente este ente é o único privilegiado que pode ter acesso ao ser, ou seja, é o único ente que pode perguntar pelo ser. Quando Heidegger pergunta: qual é o ente do qual poderemos extrair o sentido do ser? Qual é o ente no qual deve ter início a abertura do ser? O ponto de partida é indiferente ou existe um ente que pode reivindicar a primazia? (2005, p.32). É o ente. Por ter uma relação com o ser, esta primazia pertence ao ente. Ele é capaz de abarcá-lo; de percebê-lo; de questioná-lo. A este ente, que pergunta pelo sentido do ser, Heidegger chamou de ser-aí (Dasein). Com isso, Heidegger quer caracterizar o ente que tem a capacidade de buscar o sentido do ser. O Dasein quer expressar a condição do ser-no-mundo, presença no mundo como condição; mundo como um conjunto de instrumentos e possibilidades para o Dasein. Um ser-no-mundo também é um ser-com-os-outros, como um desdobramento. Nesse sentido, o ser não é pensado como um solitário no mundo. O ser-com-os-outros é a condição de participar do mundo com os outros e dele vivenciar as projeções das ações e dos comportamentos (REALE; ANTISERI, 2006, p.204-205). Para Heidegger, o ser-aí é o único ente que pode compreender o traço constitutivo de seu ser no mundo. Interessa pensar a relação do ser com a linguagem em Heidegger. Assim, "no evento

\footnotetext{
Em Heidegger é o ser-que-existe ou o ser-concreto.
} 
da linguagem, é o próprio ser que se oferece como evento: 'a linguagem é a casa do ser"' (FORTE, 2003, p.105).

Passamos a relacionar revelação e linguagem, tendo como principal interlocutor o já mencionado Giorgio Agamben. Em seu texto, " $A$ ideia da linguagem", sintético e bem construído, Agamben trata da revelação a partir da linguagem. Logo de início, ele questiona um possível conteúdo para a revelação, deixando claro que a revelação, para ser tal como é, não pode "dizer e conhecer com suas próprias forças" (2015a, p.23), ou seja, se há algo que o humano pode dizer ou conhecer que dependa exclusivamente dele, não poderia ser revelação. Assim, o que a revelação "nos dá a conhecer deve ser algo que não só não teria sido possível conhecer sem a revelação" (2015a, p.23). Há uma diferença que demarca a concepção de revelação. Quando o autor traz dois exemplos bíblicos - Cristo como verbo de Deus e os judeus com o nome de Deus -, ele está demarcando um ponto de partida que distingue e, ao mesmo tempo, provoca uma relação entre revelação e linguagem:

O conteúdo da revelação não é uma verdade exprimível sob a forma de proposições linguísticas sobre o existente [...], mas, antes, uma verdade que diz respeito à própria linguagem, ao próprio fato de que a linguagem é (AGAMBEN, 2015a, p. 24).

Supor que a revelação pode ser limitada em um livro, como preconizam segmentos conservadores da teologia, por exemplo, é não fazer a devida distinção entre o conteúdo da revelação e a própria revelação. A revelação só é revelação quando esta não pode ser pronunciável. Assim, "o sentido da revelação é que o homem pode revelar o existente através da linguagem, mas não pode revelar a própria linguagem" (AGAMBEN, 2015a, p. 24). A própria linguagem é o dado revelador para Agamben. Aqui reside o nosso interesse e suas aproveitáveis consequências para a reflexão teológica. Para o filósofo italiano, "o homem vê o mundo através da linguagem, mas não vê a linguagem" (AGAMBEN, 2015a, p. 24). E é esse o cerne da revelação. Essa invisibilidade do que (ou de quem) se revela, se mostra, mas não se vê. O que é revelado, nesse sentido, é o próprio desvelamento. O desvelamento é abertura e conhecimento no mundo (por meio da linguagem), mas não é a revelação em si: "não existe palavra para a palavra" (AGAMBEN, 2015a, p. 25).

A revelação, antes de ter sua relação com preposições linguísticas, tem uma relação estrita com a linguagem. O dizer é revelador, ou seja, "um ser do qual a simples nomeação linguística implica a existência, e esse ser é a linguagem" (AGAMBEN, 2015a, p.25). No falar e no escutar está a linguagem e é ela, a linguagem, que existe por si mesma. O que isso significa? Para Agamben, a revelação não trata de algo que significa, como se fosse possível 
apontar e dizer: é isso. Antes, a relação que se dá entre revelação e linguagem é uma relação de uma palavra "que sem significar nada, significa a própria significação" (2015a, p.26).

Qual o possível meio que a própria linguagem teria para tentar nomear o indizível? Para Agamben, seria a voz, ou seja, "a voz como pura indicação de um acontecimento de linguagem" (2015a, p.27). Aqui a voz é condicionadora da relação que se dá entre revelação e linguagem. Enquanto que, para Hegel, a voz se dá na morte, portanto, uma voz da consciência; e em Heidegger, de maneira diferente de Hegel, o ser-aí não é anterior à linguagem, assim não há um problema da voz em Heidegger, antes o humano não é conduzido à linguagem por uma voz, mas ele é jogado na linguagem pela totalidade afetiva, por isso, "entre a linguagem e a voz não há nenhuma relação" (CASTRO, 2013, p.50-51). Entre uma voz que remete para a consciência animal (Hegel) e uma voz que não diz nada (o silêncio de Heidegger), Agamben compreende que o humano carece de um fundamento, ou seja, o humano não está "consignado ao nada" (CASTRO, 2013, p.52). Ele procura outro lugar para a voz. No texto em questão (“ $A$ ideia da linguagem”), Agamben irá apresentar o doador dessa voz: "essa doação de uma voz para a linguagem é Deus, é a palavra divina. O nome de Deus, isto é, o nome que nomeia a linguagem, é, portanto [...] uma palavra sem significado" (2015a, p.27). Quando há uma nomeação para a revelação (Deus), está se estabelecendo um conteúdo, portanto, há uma metalinguagem, mas, mesmo assim, Agamben adverte não se tratar de um discurso significante, antes de "uma pura voz insignificante" (2015a, p.27). O incompreensível é o ponto em que se dá a revelação. A voz é a tentativa da pronúncia daquilo que é indizível, sendo, assim, "pura indicação de um acontecimento de linguagem" (2015a, p. 27). Agamben não trata a voz como encontro com a revelação.

No centro do seu texto, o filósofo costura suas ideias em torno da revelação e linguagem. Se entendemos bem o seu arrazoado, a linguagem é o ponto fulcral do seu raciocínio, quando se concebe o divino e sua manifestação. A linguagem não dá conta do nome, por isso "não há nome para o nome, não há metalinguagem, nem na forma de uma voz insignificante" (AGAMBEN, 2015a, p.30). Agora que o nome é incompreensível e a linguagem é a possibilidade, Agamben sentencia tendo o niilismo como fato: "Se Deus era o nome da linguagem, 'Deus está morto' pode significar apenas: já não existe um nome para a linguagem” (AGAMBEN, 2015a, p.30). No niilismo, não há fundamento. A ausência de fundamento lança o humano na linguagem. A metalinguagem já não tem sentido em um contexto niilista: "Encontramo-nos assim, finalmente, a sós com nossas palavras, pela 
primeira vez a sós com a linguagem, abandonados por todo o fundamento" (AGAMBEN, 2015a, p.30). O que resta, portanto, é a linguagem. Agora, conscientes da linguagem, o nome que poderia ser nomeado (Deus, ser, espírito, inconsciente) não é outra coisa senão nomes da linguagem. Agamben deixa transparecer que a linguagem é o que resta e não há nada para além dela, linguagem. Essa virada é significativa, e qualquer tentativa de dizer o contrário é retrógado. A religião que não se dá conta disso é retrógada, em relação ao novo contexto. Diante disso, resta saber que "os véus que a teologia, a ontologia e a psicologia estenderam sobre o humano estão agora retirados e restituídos, um a um, a seu lugar próprio na linguagem” (2015a, p.30). Esses véus foram removidos e o que ficou foi a linguagem e revelou o que era indizível.

$\mathrm{O}$ caminho que o niilismo traçou está dado: não existe nada a revelar. $\mathrm{O}$ último véu é o nada. Esse seria "o último nome da linguagem" (AGAMBEN, 2015a, p.30). Agora, cabe a pergunta: "É possível um discurso que, sem ser uma metalinguagem nem mergulhar no indizível, diga a própria linguagem e exponha seus limites?” (AGAMBEN, 2015a, p.31). A teologia ainda daria conta desse discurso? A experiência religiosa concebe uma narrativa que não seja metalinguagem e não apele para o indizível? Há uma consciência de que a própria linguagem tem seus limites e, portanto, haverá outros nomes? Essas são questões que interessam quando se pensa na experiência religiosa e sua relação com a linguagem.

\section{Linguagem como revelação}

O texto que nos ocuparemos aqui será "Lingua e história: categorias linguísticas e categorias históricas no pensamento de Benjamim" (AGAMBEN, 2015a, p.33). Nesse texto, Agamben faz um diálogo com Benjamim em torno do problema da linguagem. No texto anterior, Agamben se preocupou em demonstrar o lugar da revelação e sua relação com a linguagem e a voz. No final do texto, ele admite um niilismo e, portanto, a ausência de um fundamento. No texto em questão ("Lingua e história..."), o ato da fala é o fundamento, ou seja, “a ausência de fundamento de todo ato de fala - funda, ao mesmo tempo, a teologia e a história. Enquanto o homem não puder encontrar fundo na linguagem, existirá a transmissão dos nomes" (2015a, p.36). A discussão que Agamben abre com Benjamim se dá em torno da pura língua. Percebemos que ele, nesse ensaio, quer tratar de algo que seja anterior à linguagem, mas não procura um fundamento que esteja fora da fala (da língua). É nesse sentido que Agamben comenta um fragmento de Benjamim: 
Perante ela, a pura língua dos nomes é exemplo de uma concepção da língua que 'não conhece nenhum meio, nenhum objeto e nenhum destinatário da comunicação'. O nome, como a 'mais íntima essência da própria linguagem', é aquilo 'através do qual não se comunica nada, e no qual a língua se comunica a si mesma absolutamente. No nome, a essência espiritual que se comunica é a língua' (AGAMBEN, 2015a, p.37).

Parece que o fundamento do fundamento que Agamben quer acentuar é a própria língua que Benjamim chama de pura língua. Isso faz sentido, quando Agamben deixa mais explícito que “o estatuto dessa língua adâmica é, portanto, o de uma palavra que não comunica nada além de si mesma, e em que, por conseguinte, essência espiritual e essência linguística coincidem" (2015a, p.38). O argumento é de que não haveria nada além da própria palavra (nome) que se pronuncia. O niilismo, levando em consideração em relação à língua, tem como consequência "que todas as línguas querem dizer a palavra que não quer dizer nada” (2015a, p.40). Aparentemente um paradoxo, mas, na verdade, no pensamento de Agamben, a concepção de que o "indizível e não-dito em toda língua é, portanto, precisamente isso que ela visa e quer dizer: a pura língua, a palavra inexpressiva" (2015a, p. 40). Essa tentativa de dizer faz a história e o destino do humano. O que resta?

Repassemos alguns argumentos de Agamben, ligando-os ao texto anterior (“A ideia da linguagem”). Naquele texto, Agamben aloca a revelação (o seu conteúdo) à própria linguagem. Não há dúvida, como vimos, de que a revelação não é outra coisa senão linguagem - "o sentido da revelação é que o homem pode revelar o existente através da linguagem, mas não pode revelar a própria linguagem" (2015a, p.24). Linguagem é revelação - "um ser do qual a simples nomeação linguística implica a existência, e esse ser é a linguagem" (2015a, p.25). Dito isso, ficou a questão por responder: se a linguagem é a própria revelação, como ela se dá? Em alguns momentos, ele irá chamar de dizer, fala ou a voz. Entendemos que são termos cambiantes. O dizer é revelador. A fala é a expressão que procura pronunciar o que seria indizível. A voz é o elemento que indica um acontecimento de linguagem. Está dada a relação revelação e linguagem quando há uma tentativa de pronunciar uma palavra, um nome. Agora, quanto ao conteúdo do dizer, da fala e da voz, da tentativa de pronunciar, Agamben é lacônico - "que sem significar nada, significa a própria significação" (2015a, p.26). Uma vez sendo a voz como "pura indicação de um acontecimento de linguagem" (2015a, p. 27), ela pode ter um doador, que pode ser "Deus". O que é Deus? Agamben não discorre... Agora ele vai além e confirma que a voz é a tentativa da pronúncia daquilo que é indizível, portanto, pode ser Deus ou o ser, ou ainda qualquer outro nome. Por essa razão, ele abarca o niilismo: "Se Deus era o nome da 
linguagem, 'Deus está morto' pode significar apenas: já não existe um nome para a linguagem” (2015a, p. 30). O fundamento não é mais verificável. Respondendo à pergunta, o que resta... Resta a linguagem: "pela primeira vez a sós com a linguagem, abandonados por todo o fundamento" (2015a, p. 30).

Diante desse quadro, Agamben nos faz pensar em possibilidades, se admitido o fato de que não há mais fundamento e a linguagem é o que nos resta. Quase no final do seu texto, ele deixa o raciocínio em plano ambíguo, mas não tão solto como gostaríamos:

Pensar o que seria uma comunidade humana e uma língua humana que não remetessem para nenhum fundamento indizível e não se destinassem mais a uma transmissão infinita, e em que as palavras já não se distinguissem de toda outra práxis humana é, certamente, uma tarefa árdua (AGAMBEN, 2015a, p. 48).

No nosso entender, sendo possível equívocos na interpretação do pensamento de Agamben, essa "tarefa árdua" ele intentou realizar nesses dois textos com as ideias que procurou articular em torno da linguagem. Entendemos assim, por ele complementar na sequência: "Mas isso, e nada menos que isso, é o que um pensamento que queira estar verdadeiramente à altura de seu problema tem de pensar" (2015a, p.48). Ele está fazendo isso, pensando sobre problemas que atingem o humano na sua radicalidade e que procura, como na história da filosofia, sentido, o que significa que possa encontrar um (niilismo), mas, mesmo assim, procura... O encontro, no nosso entender, se dá com a linguagem e ela, somente ela, é o que resta. As implicações dessa assertiva são inúmeras, principalmente quando se pensa na teologia e o seu esboço linguístico que procura nomear e dá conteúdo ao indizível. Tarefa nossa, quando procuramos articular a teologia e sua relação com as religiões.

\section{Teologia hermenêutica e as religiões a partir da fenomenologia}

Há em curso uma tentativa de se pensar em uma teologia mundial, ou uma teologia que seja transconfessional. Essa teologia procuraria dar conta da diversidade religiosa, formulando, assim, uma teologia para além das confissões religiosas e que, concomitantemente, servisse para as religiões. Entendemos que tal empreendimento não é possível. Compreendemos, também, que se trata de procurar livrar a teologia do seu codinome cristão e, para isso, uma teologia mundial seria o caminho mais promissor. Ocorre que há um pluralismo religioso com todas as suas implicações teológicas, ainda mais quando acolhemos as intuições de Agamben, quando relaciona linguagem com revelação e a procura por nomear o indizível. Sendo assim, concordamos com Agenor Brighenti, quando discorda dessa pretensão: "Um 
tal pluralismo teológico esbarra em dois obstáculos: de um lado, está a singularidade das diversas experiências religiosas, de outro lado está a singularidade das múltiplas matrizes culturais que dão suporte a tais experiências" (2011, p. 84). O pluralismo religioso, per si, já constitui um enorme desafio para a teologia. Um pluralismo teológico é um projeto que se faz inviável, quando as diferentes religiões buscam acentuar a sua identidade diante do mundo. Por essa razão, Brighenti pontua: "Se já não fosse pequeno o desafio da singularidade das diversas tradições religiosas, soma-se a ele a singularidade das múltiplas matrizes culturais, não só em relação às diferentes confissões, como no seio de cada confessionalidade" (2011, p.84). É nesse sentido que acentuamos uma teologia hermenêutica, até porque "não existe 'revelação' não inculturada, o que faz da teologia discurso 'sobre' o Absoluto e não um discurso absoluto. A teologia é sempre um produto humano” (2011, p.87). Está dada a condição sine qua non da teologia, qual seja, o seu caráter hermenêutico. Como hermenêutica, a teologia se entende como narrativa, antes de ser dogmática (SALLES, 2010, p.82). Na teologia como hermenêutica, o pressuposto metafísico deixa de ter a sua prioridade, ou seja, quando ela (a teologia) se apropria da hermenêutica, concebe um "discurso que reflete sobre a linguagem sobre Deus, um discurso sobre uma linguagem que fala humanamente de Deus" (GEFFRÉ, 2010, p. 33).

Diante disso, podemos alocar as religiões na discussão teológica, uma vez que o dado hermenêutico é constitutivo da linguagem teológica. Assim, uma "teologia das religiões", para se comprometer com os enunciados que estamos elencando aqui, teria uma perspectiva fenomenológica anterior ao aspecto doutrinário. Antes desse projeto ter a sua validade, é admitido que, a essa altura, a teologia, em um contexto de pluralismo religioso, está despida de "querer possuir todo o saber, toda a compreensão da realidade, a partir de uma única perspectiva" (SALLES, 2010, p.84). O debate doutrinário perpassa boa parte dos pesquisadores e teólogos quando a pauta é "teologia cristã das religiões", o pluralismo religioso e o seu corolário, o diálogo inter-religioso. A perspectiva fenomenológica das religiões, quando discutida pela teologia que concebe a linguagem como primeira e a hermenêutica como meio, ainda se faz de maneira escassa. Teólogos de tradição católica, comprometidos com o tema das religiões, estão engajados nos anúncios da Igreja por meio dos seus documentos oficiais quanto à temática das religiões. Assim, a árdua tarefa deles é "justificar a universalidade da salvação cristã diante de outras religiões” (MIRANDA, 1998, p.13). Quanto ao debate em torno das religiões e o aspecto salvífico delas, os documentos da Igreja precisam ser levados em consideração, mesmo que apresentem limites e reducionismo na abordagem. 
Essa é uma preocupação indispensável para os teólogos de tradição católica, em que a não observação de algum elemento presente nos textos pode, invariavelmente, ocasionar em consequências que variam desde advertências (como foi com Jacques Dupuis, por exemplo) ou, até mesmo, o banimento (como foi com Hans Küng). Por essa razão, quando Faustino Teixeira elabora a sua Teologia das religiões: uma visão panorâmica (1995, p.115-179), ele dedica toda a segunda parte da obra para tratar dos inúmeros documentos que a Igreja emitiu sobre a temática das religiões, demonstrando, em alguns deles, avanços quanto à abertura para o diálogo, mas também retrocessos.

Mesmo admitindo a pluralidade da experiência de "Deus" nas religiões, por conta das diferentes tradições culturais, e ainda consciente de que "toda experiência é experiência interpretada" (MIRANDA, 1998, p.32), ainda assim há uma recusa pelo aspecto fenomenológico, sendo diminuído seu alcance quando em contato com outras tradições religiosas. ${ }^{5} \mathrm{O}$ argumento é de que o "recurso ao bumanum não convence por se tratar de um critério meramente fenomenológico, que tornaria a teologia das religiões dependente da antropologia dominante em cada época" (MIRANDA, 1998, p.23).

Uma proposta de teologia das religiões (ou de teologia do pluralismo religioso) que não passe, necessariamente, pelo debate doutrinário - quer dizer, o aspecto dogmático em torno de Cristo, da salvação e da missão da Igreja -, num primeiro instante aparenta ser inviável.

Aqui, desenhamos uma abordagem da teologia no seu aspecto hermenêutico, portanto, como linguagem para falar do sagrado. Nessa teologia, quando em contato com as religiões, a relação se dá a partir da fenomenologia. Como teologia fenomenológica, queremos sublinhar o aspecto anterior de uma teologia das religiões, ou seja, antes de uma abordagem doutrinária, as religiões têm suas experiências com o sagrado e isso se constitui em fenômeno, acessível por meio da linguagem, que necessita de uma hermenêutica para traduzir uma revelação que se mostra indizível. Assim, "a experiência do sagrado nunca é dada sem mediações, e nunca acontece sem que haja, direta ou indiretamente, a mediação linguística através de textos e discursos" (JOSGRILBERG, 2012, p.49). A partir disso, não seria possível considerar o cristianismo, por exemplo, como única religião fora dessa dinâmica. A impressão que temos é de que os textos e a experiência do sagrado no cristianismo se constituem normativos para as outras tradições religiosas como se ele (o cristianismo), também não estivesse dentro dessa mesma dinâmica. Por essa razão, uma teologia fenomenológica seria possível, porque resgataria

5 Para o aspecto fenomenológico das religiões: BELLO, Angela Ales. Culturas e religiões: uma leitura fenomenológica. 2. ed. Bauru: EDUSC, 1998. 
o aspecto narrativo da teologia e assim, a teologia tem o seu lugar específico quando diante de uma linguagem mítica das religiões, sendo uma ferramenta de leitura e análise das tradições religiosas, inclusive do cristianismo. Com isso, a teologia se ocuparia "como um discurso sobre mitos, ritos e símbolos. Ela passaria a ser vista como formulação conceitual, o mais rigoroso possível, destes caracteres simbólicos" (GROSS, 2008, p.329). Em outras palavras, a teologia, quando na sua abordagem fenomenológica e, depois, como condição hermenêutica para a leitura religiosa, teria condições de criticar os "sistemas interpretativos da religião - os sistemas teológicos -, enquanto hermenêutica da sua dimensão radical de sentido" (HIGUET, 2006, p.41). As condições para que a abordagem aqui proposta seja refletida estão mais para o campo do protestantismo, por conta da ausência de um modelo normatizador, como tem a tradição católica. Se essa observação estiver correta, a teologia das religiões, a partir dos elementos que a compõem e que foram ressaltados, teria mais condições de ser trabalhada na perspectiva protestante. Aí, poderíamos pensar em uma teologia na qual o ponto de partida não esteja "nos dogmas oficiais e, tampouco, num modelo teológico normativo confessional, mas na experiência humana concreta, postulando a presença de uma dimensão religiosa em toda experiência autêntica" (HIGUET, 2006, p.41).

\section{Considerações finais}

A principal pergunta que esse texto procurou responder é sobre a possibilidade de uma teologia das religiões em que o aspecto doutrinário não seja o primeiro e principal elemento de aproximação das religiões. Os autores que tratam do tema (teologia das religiões), abordam diferentes aspectos da relação entre teologia e religiões. Quando tomamos conhecimento de uma seleção desses autores (RIBEIRO; SOUZA, 2012), é possível perceber que a preocupação se dá, na sua maioria, por teólogos católicos, em torno da perspectiva salvífica. Autores protestantes são raros dentro dessa temática, ou seja, não há uma quantidade expressiva de teólogos de tradição protestante refletindo teologia das religiões, embora haja pesquisadores que vêm procurando preencher essa lacuna no contexto latino-americano.

$\mathrm{O}$ que permeou nosso texto foram algumas questões levantadas em torno do tema teologia das religiões e sua estreita relação com a perspectiva cristã. A teologia das religiões de perspectiva cristã procura fazer, majoritariamente, uma leitura das religiões a partir do aspecto doutrinário, desconsiderando, embora admitindo, o fato de que também, como religião, está dentro de um sistema que envolve linguagem e hermenêutica. Mesmo reivindicando a revelação como centro gravitacional para subsistir, a teologia se constitui 
como linguagem, portanto, dependente de uma ciência, a hermenêtica, para dizer o que pretende. A teologia das religiões como hermenêutica precisa olhar para as demais experiências religiosas a partir do aspecto fenomenológico. Com isso, haveria maior abertura para o diálogo entre-fés, sabendo que a fé é elemento constitutivo do humano nas religiões.

\section{Referências bibliográficas}

AGAMBEN, Giorgio. A potência do pensamento: ensaios e conferências. Belo Horizonte: Autêntica, 2015a.

AGAMBEN, Giorgio. Nudez. Belo Horizonte: Autêntica, 2015.

BRIGHENTI, Agenor. Teologia e pluralismo religioso: questões metodológicas. In: VIGIL, José María (Org.). Por uma teologia planetária. São Paulo: Paulinas, 2011, p. 81-91.

CASTRO, Edgardo. Introdução a Giorgio Agamben: uma arqueologia da potência. Belo Horizonte: Autêntica, 2013.

FORTE, Bruno. À escuta do outro: filosofia e revelação. São Paulo: Paulinas, 2003.

GADAMER, Hans-Georg. Verdade e método: traços fundamentais de uma hermenêutica filosófica. 3. ed. Petrópolis: Vozes, 1999.

GEFFRÉ, Claude. Crer e interpretar: a virada hermenêutica da teologia. Petrópolis: Vozes, 2004.

GEFFRÉ, Claude. De Babel a Pentecostes: ensaios de teologia inter-religiosa. São Paulo: Paulus, 2013.

GONÇALVES, Paulo Sérgio Lopes. A teologia na cultura pós-moderna. In: SOUZA, Ney de (Org.). Teologia em diálogo: os desafios da reflexão teológica na atualidade. Aparecida: Santuário, 2010, p. 13-64.

GROSS, Eduardo. Considerações sobre a teologia entre os estudos da religião. In: TEIXEIRA, Faustino (Org.). A(s) ciências(s) da religião no Brasil: afirmação de uma área acadêmica. 2. ed. São Paulo: Paulinas, 2008, p. 323-346.

HEIDEGGER, Martin. Ser e tempo. Parte I. 15. ed. Petrópolis: Vozes, 2005.

HIGUET, Etienne A. A teologia em programas de ciências da religião. Correlatio, n. 9, p. 37-51, 2006.

JOSGRILBERG, Ruy de Souza. Hermenêutica fenomenológica e a tematização do sagrado. In: NOGUEIRA, Paulo A. de S. (Org.). Linguagens da religião: desafios, métodos e conceitos centrais. São Paulo: Paulinas, 2012, p. 31-67.

LAGO, Samuel (Org.). O melhor de Rubem Alves. 2. ed. Curitiba: Nossa Cultura, 2009.

LATOUR, Bruno. Jamais fomos modernos: ensaio de antropologia simétrica. 3. ed. São Paulo: Editora 34, 2013.

MIRANDA, Mário de França. O cristianismo em face das religiões. São Paulo: Loyola, 1998.

MOLTMANN, Jürgen. Experiências de reflexão teológica: caminhos e formas da teologia cristã. São Leopoldo: UNISINOS, 2004. 
OLIVEIRA, Manfredo Araújo de. Reviravolta linguístico-pragmática na filosofia contemporânea. São Paulo: Loyola, 2001.

PANNENBERG, Wolfhart. Filosofia e teologia: tensões e convergências de uma busca comum. São Paulo: Paulinas, 2008.

PRIGOGINE, Ilya. O fim das certezas: tempo, caos e as leia da natureza. 2. ed. São Paulo: UNESP, 2011.

REALE, Giovanni; ANTISERI, Dario. História da filosofia: de Nietzsche à Escola de Frankfurt. Vol. 6. São Paulo: Paulus, 2006.

RIBEIRO, Claudio de Oliveira; SOUZA, Daniel Santos. A teologia das religiões em foco: um guia para visionários. São Paulo: Paulinas, 2012.

RIBEIRO, Claudio de Oliveira. Pluralismo e libertação. São Paulo: Paulinas, 2014.

RIPANTI, Graziano. Hans-Georg Gadamer: a alteridade da hermenêutica teológica. In: PENZO, Giorgio; GIBELLINI, Rosino (Orgs.). Deus na filosofia do século XX. 2. ed. São Paulo: Loyola, 1998, p. 373-381.

SALLES, Walter Ferreira. O pluralismo religioso e a dimensão hermenêutica da identidade cristã. In: SOUZA, Ney de (Org.). Teologia em diálogo: os desafios da reflexão teológica na atualidade. Aparecida do Norte: Santuário, 2010, p. 64-116.

SANTANA FILHO, Manoel Bernardino. Revelação. In: BORTOLLETO, Fernando (Org.). Dicionário brasileiro de teologia. São Paulo: ASTE, 2008, p. 876-878.

SOUSA, Mauro Araújo de. Nietəsche: viver intensamente, tornar-se o que se é. São Paulo: Paulus, 2009.

TEIXEIRA, Faustino. Teologia das religiões: uma visão panorâmica. São Paulo: Paulinas, 1995.

VIGIL, José María. Teologia do pluralismo religioso: para uma releitura pluralista do cristianismo. São Paulo: Paulus, 2006.

ZILLES, Urbano. Desafios atuais para a teologia. São Paulo: Paulus, 2011.

ZILLES, Urbano. Filosofia da religião. 4. ed. São Paulo: Paulus, 2002.

Submetido em: 31-8-2017

Aceito em: 11-12-2017 